\title{
Professionalism: The view from outside medicine
}

$\mathrm{T}$ here have been journal articles, commentaries and editorials galore. There have been codes, charters and changes to medical curricula. There have been crisis warnings, rallying cries and rhetoric thicker than refrigerated gravy.

Oodles of hours, tonnes of text and wads of worry - all in the name of improving professionalism in medicine. The point of this effort, according to many physicians, is to rescue medicine from the clutches of commercialism. Even cynics would have trouble slamming that.

Still, if one wanted to find fault with this doctor-led professionalism movement, there is, according to outside observers, a rather glaring one. The whole thing is rather insular. To paraphrase the work of Frederic Hafferty, a sociologist, it mostly consists of doctors citing other doctors' writings on professionalism in their own articles on professionalism for an audience of doctors interested in professionalism.

Medicine, consider thy navel adequately gazed.

"You have these internal conversations going on within medicine, but not as much of a conversation in the public," says Hafferty, a professor of medical education and associate director of a program in professionalism and ethics at the Mayo Clinic in Rochester, Minnesota.

Physicians interested in an outsider's view of medical professionalism would be wise to look to the field of sociology. For more than a century, sociologists have studied the concept of a profession - a collection of highly educated, self-regulated individuals who deliver complex services to society, ideally in an altruistic fashion - as well as the ideals professionals are supposed to uphold when they are granted the right to self-regulation and have a responsibility to ensure that members are acting professionally. Evaluating professionalism in medicine from the outside, as a neutral observer rather than a passionate practitioner, can pro-

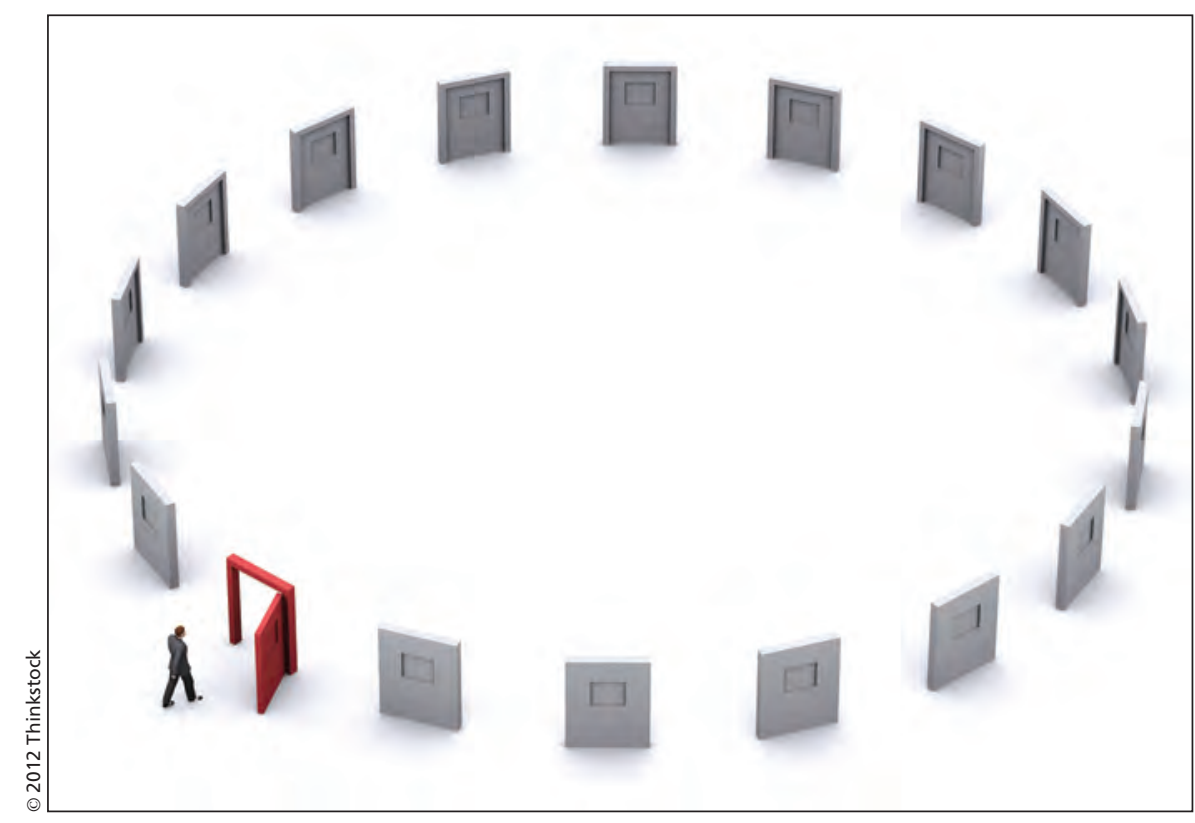

Sociologists opening a door into the world of medical professionalism would look to determine whether health organizations are structured to assess the concept, while physicians typically view it in terms of the motives and behaviours of practitioners.

vide insights unlikely to arise within the profession itself.

Many physician-penned articles on professionalism, for instance, tend to focus on changing the behaviour of individuals. They call for practising doctors to re-embrace the core values of altruism that have faded in an era of medicine controlled by corporations and governments. They call for medical students to be educated about "old school" professional ideals. Sociologists, on the other hand, look at the topic through a wide-angle lens. They ask different questions. Are health organizations structured to promote professionalism? Are hospitals able to assess the professionalism of health workers?

"In a nutshell, where sociology had emphasized social structures, jurisdictional issues of influence, and themes such as power and privilege, medicine's own professionalism was more about the motives and behaviors of individual practitioners and students," Hafferty and a colleague (Brian Castellani) wrote in "Two Cultures: Two Ships: The Rise of a Professionalism Movement Within
Modern Medicine and Medical Sociology's Disappearance from the Professionalism Debate," chapter 11 of the Handbook of the Sociology of Health, Illness, and Healing (www.springerlink .com/content/q831w4579306163j).

"Organized medicine wanted to rally and incite its troops," they added. "Sociology wanted to understand the war."

Because the professionalism movement within medicine has largely been viewed as a response (to external influences such as commercialism) rather than a quest for knowledge, it has been prone to longings for a return to a "golden age" of medicine, when doctors enjoyed more autonomy and respect, and were less driven by financial interests. Sociologists have dubbed this "nostalgic professionalism."

But there are several potential pitfalls to forcing the past onto the present. For one, there will be pushback from medical students and young physicians, who, failing access to time machines, possess no tender memories of an era that ended before they were born. Young medical professionals place 
more value than their senior counterparts on work-life balance. They want to see their families and take vacations and occasionally get a full night's sleep. Some older doctors - of the 24/7, patients-comes-first, work-until-dead variety - aren't so fond of this attitude.

Looking to the past for modern solutions can also blind one to context. In the United States, for example, the health care system is largely controlled by corporations. It is market-driven. In that they are either altruistic or, with gentle prodding, can become altruistic.

A more realistic outlook, however, might be that people enter various professions for various reasons and with varying levels of competence, and doctors are no different. Yes, some are unquestionably passionate about improving the lives of patients. But it would be naive, perhaps, to claim some aren't motivated by other factors - job security, the intellectual challenges the field presents, the

\section{"But let's put altruism on a scale. A 10 puts you at saint-doctor. If you are dodging bullets and risking infection, let's assign that a 10." - Michael Yeo, associate professor of philosophy at Laurentian University.}

context, it might be more productive, sociologists suggest, for US physicians to consider how their professionalism fits into this context rather than cling to oldfashioned principles. Professionalism advocates also tend to assume patients will readily embrace medical values of yore - thereby boosting public trust in medicine, which has been slipping. But who's to say that will actually happen?

"To date, organized medicine continues to call upon its 'troops' to rally behind a distinctly "old school" view of professionalism - with little acknowledgement that there are serious schisms within medicine's ranks (particularly among trainees) about what it means to be a professional in the age of 'big business' and corporately controlled health care systems," wrote Hafferty and Castellani. "Furthermore, medicine's entire professionalism movement is predicated on the need - as identified by medicine - to reestablish public trust, but with that goal grounded in the belief that the public will uncritically and unreservedly respond to medicine's overtures (the field of dreams scenario)."

Another problem with having medical professionals assess medical professionalism is that they can, at times, be Pollyannaish, if not completely defensive, about their own kind. There tends to be an attitude within the profession that doctors are inherently "good," that prestige of being called Dr. So-and-so rather than Mr. or Ms. So-and-so.

And let's not forget about money. After all, doctors aren't setting broken bones and peering down phlegmy throats out of the goodness of their hearts. They are compensated for caring for patients - often quite handsomely, depending on their specialty. So all this talk of altruism, an outsider might say, can be a bit much. Some people are very altruistic, others less so, still others not at all - MD or no MD.

"The argument is that altruism is an essential feature of the culture of medicine," says Michael Yeo, associate professor of philosophy at Laurentian University in Sudbury, Ontario. "But let's put altruism on a scale. A 10 puts you at saint-doctor. If you are dodging bullets and risking infection, let's assign that a $10 . "$

All this is not to say, of course, that the professionalism movement within medicine isn't valuable, if not necessary. After all, self-regulation implies a measure of responsibility and doctors do have a duty to provide good care.

It boils down to a discussion about how to be a good doctor, says Hafferty, and that is a discussion worth having. "I honestly didn't believe when all this stuff started in the 80s that it would have the legs that it has had," he says. "That's a great compliment to medicine."
It also encouraging, he says, to see that some people are moving the discussion beyond doctors and medical students. He points, by way of example, to a document released by the Society for Cardiothoracic Surgery in Great Britain and Ireland called Maintaining patients' trust: modern medical professionalism 2011 (www.scts.org/_userfiles /resources/634420268996790965_SCTS _Professionalism_FINAL.pdf).

"They include quality of care. It's not a separate topic. In the US, it's considered a separate topic," says Hafferty. "This is all about patients. This is an updated professionalism, about quality of care and evidence-based medicine. They are saying, 'We are doing this because it's the professional thing to do. We are holding ourselves up to a high standard, and doing it to ensure the trust of the public." - Roger Collier, CMAJ

\section{CMAJ 2012. DOI:10.1503/cmaj.109-4257}

Editor's note: Tenth in a multipart series on medical professionalism.

Part I: The "good doctor" discussion (www.cmaj.ca/lookup/doi/10.1503 /cmaj.109-4200).

Part II: What is it? (www.cmaj.ca /lookup/doi/10.1503/cmaj.109-4211).

Part III: The historical contract (www.cmaj.ca/lookup/doi/10.1503 /cmaj.109-4230).

Part IV: Can it be taught?

(www.cmaj.ca/lookup/doi/10.1503 /cmaj.109-4232).

Part V: Social media outreach (www.cmaj.ca/lookup/doi/10.1503 /cmaj.109-4207).

Part VI: Social media mishaps (www.cmaj.ca/lookup/doi/10.1503 /cmaj.109-4209).

Part VII: Logging on to tell your doctor off (www.cmaj.ca/lookup /doi/10.1503/cmaj.109-4205).

Part VIII: Assessing physician behaviour (www.cmaj.ca/lookup /doi/10.1503/cmaj.109-4240).

Part IX: How payment models affect physician behaviour (www.cmaj.ca /lookup/doi/10.1503/cmaj.109-4250). 